\title{
PEMBUATAN DAN UPAYA PENINGKATAN KUALITAS PUPUK ORGANIK CAIR
}

\author{
Production and Effort to Improve the Quality of Liquid Organic Fertilizer
}

\author{
Dedy Prasetyo $^{1}$ dan Rusdi Evizal ${ }^{2 *}$
}

\author{
${ }^{1}$ Jurusan Ilmu Tanah, Fakultas Pertanian, Universitas Lampung \\ ${ }^{2}$ Jurusan Agroteknologi, Fakultas Pertanian, Universitas Lampung \\ Jl. Sumantri Brojonegoro No 1 Gedung Meneng, Bandar Lampung 35145 \\ *E-mail korespondensi: rusdi.evizal@fp.unila.ac.id
}

\begin{abstract}
ABSTRAK
Praktik pertanian konvensional sangat intensif memanfaatkan agrokimia sintetik. Dampak yang ditumbulkan adalah penurunan kualitas tanah sehingga menurunkan efisiensi pemupukan dan produktifitas tanaman. Upaya menjaga kesehatan tanah antara lain dengan mengembalikan bahan organik. Pupuk organik dapat dihasilkan dengan memanfaatkan limbah pertanian disekitar. Untuk meningkatkan kandungan hara pupuk organik cair (POC) maka perlu dipilih bahan yang mengandung unsur hara yang tinggi terutama hara makro. Kualitas POC dapat ditingkatkan dengan pemberian starter komersial maupun mikro organisme lokal (MOL) dan bahan pendorong pertumbuhan dekomposer. Proses pembuatan pupuk organik cair memanfaatkan proses fermentasi secara aerob dan anaerob. Mikroba akan mendekomposisi bahan organik dengan mengurai unsur hara di dalam bahan menjadi larut dalam larutan. Aplikasi POC sudah banyak diuji pada berbagai komoditas pertanian. Pemberian POC mampu meningkatkan pertumbuhan dan hasil tanaman serta meningkatkan kesehatan tanah.
\end{abstract}

Kata kunci: Anaerob, buah, fermentasi, hijauan, industri, limbah, MOL, mutu, sayur, POC, pulp

\begin{abstract}
Conventional agricultural practices are very intensively utilizing synthetic agrochemicals. The resulting impact is a decrease in soil quality, thereby reducing fertilizer efficiency and plant yield. Efforts to maintain soil health include restoring organic matter. Organic fertilizers can be produced by utilizing the surrounding agricultural waste. Liquid organic fertilizer (LOF) can be produced from organic waste which should be chosen from high content of macro nutient. The quality of LOF could be improved by adding commercial decomposer starter or local microorganism. Organic matter of high energy should be added as well. The process of making liquid organic fertilizer is involved an arobic or anaerobic fermentation. Microbes will decompose organic material by breaking down the nutrients in the material to dissolve in solution. LOF applications have been tested on various agricultural commodities. The provision of LOF can increase the growth and yield of plants. In addition, the use of LOF can improve soil health.
\end{abstract}

Keywords : Anaerob, fermentation, fruit, industry, LOF, microbe, pulp, quality, vegetable, waste

\section{PENDAHULUAN}

Lahan pertanian pada umumnya mengandung unsur hara yang sangat dibutuhkan sebagai nutrisi bagi tanaman. Ketersediaan nutrisi yang berimbang dapat menjaga produktivitas tanaman dan keberlanjutan lahan. Tanaman menyerap unsur hara secara terus menerus, sehingga mengakibatkan petani perlu menambahkan pupuk dalam kegiatan budidaya seperti pupuk anorganik (Rahmad et al., 2018). 
Pemberian pupuk anorganik serta agrokimia sintetik oleh petani terkadang melebihi rekomendasi yang telah ditetapkan atau dianjurkan (Darwis, 2014). Dampak yang ditimbulkan antara lain penurunan kualitas tanah baik sifat kimia, fisika maupun biologi yang dapat menurunkan produktivitas tanah dan tanaman (Hartati et al., 2014).

Selain memperhatikan kebutuhan nutrisi bagi tanaman, kesehatan tanah dalam konsep pertanian berkelanjutan perlu dikonservasi. Tanah yang sehat memiliki sifat kimia, fisika, dan biologi yang ideal untuk menunjang produktivitas tanaman dan keberlanjutan lahan (USDA-NRCS, 2019). Kesehatan tanah merupakan kemampuan tanah berperan sebagai ekosistem kehidupan untuk menunjang keberlanjutan dari tanaman, hewan dan manusia serta menjaga dari degradasi lahan (Miner et al., 2020). Upaya dalam menjaga kesehatan tanah antara lain dengan mengembalikan bahan organik. Tindakan yang dapat dilakukan antara lain pemberian pupuk organik, baik dalam bentuk padat maupun cair.

Pupuk organik merupakan hasil aktivitas mikrobiologi dalam merombak bahan organik, dan memiliki sifat slow release (lambat tersedia) namun dapat tersedia lebih lama di dalam tanah dibandingkan pupuk anorganik (Ameeta dan Ronak, 2017). Pemberian pupuk organik juga berperan dalam meningkatkan aktivitas mikroba tanah, menekan keberadaan penyakit tanaman (Tonfack et al., 2009) dan meningkatkan efisiensi penyerapan unsur hara (Ameeta dan Ronak, 2017), sehingga dapat menjaga atau meningkatkan produktivitas tanah dan tanaman. Pupuk organik dapat dihasilkan dari limbah-limbah pertanian dengan metode fermentasi atau pengomposan sehingga menghasilkan pupuk organik dengan bentuk cair ataupun padat.

Pupuk organik cair (POC) merupakan pupuk organik hasil fermentasi berbentuk cair dan memiliki keunggulan lebih mudah terserap oleh tanaman, mengandung unsur hara makro dan miro yang cepat tersedia
(Hadisuwito, 2007; Febrianna et al., 2018). Bahan-bahan yang dapat digunakan sebagai bahan baku pembuatan pupuk organik cair relatif mudah didapatkan. Bahan yang dapat digunakan sebagai pupuk cair diantaranya bonggol pisang, ampas tahu (Maunte, 2018), dan akar bambu (Syamsiah, 2019). Selain itu dalam pembuatannya dapat diperkaya dengan bahan organik padat seperti kotoran ayam (Febrianna et al., 2018) dan urine kelinci (Syamsiah, 2019) agar kandungan unsur hara lebih tinggi. Artikel ini akan memberikan kajian mengenai cara pembuatan dan upaya peningkatan kualitas POC yang dihasilkan.

\section{MANFAAT PUPUK ORGANIK CAIR}

Pupuk Organik Cair (POC) adalah larutan hasil dari pembusukan bahan organik yang berasal dari sisa tanaman, kotoran hewan dan manusia yang kandungan unsur haranya lebih dari 1 unsur. Menurut Hadisuwito (2007) pupuk organik cair adalah larutan yang berasal dari hasil pembusukan bahan-bahan organik yang berasal dari sisa tanaman, kotoran hewan, dan manusia yang kandungan unsur haranya lebih dari satu unsur. Kelebihan dari pupuk organik cair adalah sercara cepat mengatasi defisiensi hara, tidak bermasalah dalam pencucian hara, dan mampu menyediakan hara yang cepat. POC selain berfungsi sebagai pupuk dapat sebagai aktivator untuk membuat pupuk organik padat.

Pupuk organik cair merupakan jenis pupuk yang sudah banyak beredar di kalangan petani atau pasaran. Unsur hara yang terkandung di dalamnya sudah beragam hingga lengkap baik makro dan mikro esensial (N, P, K, S, Ca, Mg, B, Mo, $\mathrm{Cu}, \mathrm{Fe}, \mathrm{Mn}$, dan bahan organik). Aplikasi POC dapat memperbaiki kualitas tanah, meningkatkan produksi tanaman, meningkatkan mutu produk, dan dapat mengurangi penggunaan pupuk anorganik (Parman, 2007).

Pupuk organik cair memiliki kelebihan antara lain mengandung nutrisi 
yang cukup lengkap baik makro dan mikro, mudah diserap oleh tanaman karena mengandung unsur hara sudah terurai sehingga pemanfaatan oleh tanaman berjalan lebih cepat daripada pupuk padat (Sihotang et al., 2013). Bahan organik yang melimpah dan nutrisi yang lebih mudah diserap oleh tanaman (Solihin et al., 2019) dapat menjaga kualitas atau keberlanjutan tanah dan tanaman (Hou et al., 2017). Sumber bahan baku POC dapat menggunakan limbah pertanian yang difermentasi dalam waktu tertentu dan dapat diperkaya dengan sumber lainnya. Pupuk organik cair dapat dimanfaatkan pada berbagai komoditas pertanian, baik komoditas pangan maupun hotikultura.

Penggunaan pupuk organik cair memberikan beberapa keuntungan, misalnya pupuk ini dapat digunakan dengan cara menyiramkannya ke akar ataupun di semprotkan ke tanaman dan menghemat tenaga. Selain itu penyiraman dapat menjaga kelembaban tanah. Pupuk organik cair dalam pemupukan jelas lebih merata, tidak akan terjadi penumpukan konsentrasi pupuk di satu tempat. Karena pupuk organik cair $100 \%$ berupa larutan maka secara cepat mengatasi defesiensi hara, tidak bermasalah dalam pencucian hara, dan juga mampu menyediakan hara secara cepat (Priangga et al., 2013).

Urine sapi mengandung unsur hara $\mathrm{N}$, $\mathrm{P}, \mathrm{K}$ dan bahan organik yang berperan memperbaiki struktur tanah. Bahan ini dapat digunakan langsung sebagai pupuk baik sebagai pupuk dasar maupun pupuk cair (Hendriyatno et al., 2019). POC bio-urine sapi memiliki kandungan Nitrogen yang cukup baik dibandingkan dengan bahan pupuk cair lainnya.

Hasil penelitian Waluguru (2012) menjelaskan bahwa kandungan $\mathrm{N}$ pada urine sapi sebelum fermentasi mencapai 5,27\%, namun setelah fermentasi (2 minggu penyimpanan) sedikit mengalami penurunan tetapi tidak signifikan menjadi $5,1 \%$. Kandungan $\mathrm{N}$ pada urine sapi ternyata dapat terus menurun apabila disimpan terlalu lama. Pada penyimpanan 10 minggu, kandungan $\mathrm{N}$ turun secara signifikan menjadi 3,40\%. Pupuk organik cair urine sapi yang disimpan dapat mengalami penguapan dan atau denitrifikasi menyebabkan terjadi kehilangan $\mathrm{N}$ dalam bentuk gas. Deniritifikasi terutama terjadi pada keadaan anaerob dan menyebabkan kehilangan $\mathrm{N}$ terbesar.

Berbeda dengan unsur hara Nitrogen, Unsur $\mathrm{P}$ dan $\mathrm{K}$ dalam urine sapi pada saat awal fermentasi memiliki masing-masing sebesar 64,00 ppm dan 16,82 ppm. Namun setelah penyimpanan selama 10 minggu kadar $\mathrm{P}$ dan $\mathrm{K}$ sedikit menurun tetapi tidak menunjukkan angka yang signifikan sehingga menjadi 60,00 ppm dan $16,57 \mathrm{ppm}$. Ketersediaan P di dalam tanah mengalami peningkatan setelah pemberian pupuk organik berbahan urine sapi, sehingga unsur $\mathrm{P}$ mudah diserap oleh sel-sel akar sehingga mendukung untuk pertumbuhan tanaman (Hanifa dan Lutojo, 2014). Menurut Hendriyatno et al. (2019) aplikasi bahan organik seperti pupuk organik cair pada tanah penting manfaatnya untuk upaya mempertahankan hasil yang optimal pada tanah dalam meningkatkan efisiensi dan efektifitas pupuk anorganik.

\section{PEMBUATAN PUPUK ORGANIK CAIR}

Pupuk Organik cair dapat dihasilkan dari limbah pertanian yang sudah tidak dimanfaatkan untuk dikembalikan ke dalam tanah (Hapsari dan Welasih, 2013). Proses pembuatan pupuk organik umumnya melalui proses penguraian oleh aktivitas mikroba. Senyawa yang berasal dari bahan organik akan mudah diurai oleh mikroba dibandingkan dengan senyawa anorganik. Penguraian bahan organik atau POC melalui proses yang disebut dengan fermentasi. Limbah bahan organik akan diubah oleh mikroba menjadi senyawa yang sederhana seperti gula, gliserol, asam lemak dan asam amino (Fitria et al., 2008). 
Fermentasi merupakan proses perubahan substrat organik secara kimiawi oleh mikroba yang mampu menghasilkan enzim tertentu (Suprihatin, 2010). Supaya proses fermentasi dapat berlangsung dengan baik maka diperlukan starter mikroba. Starter merupakan komunitas atau populasi mikroba yang bertanggung jawab dalam proses dekomposisi. Lama laju fermentasi setiap bahan atau limbah organik untuk digunakan sebagai POC memiliki rentang waktu yang berbeda-beda.

Selama proses fermentasi secara tradisional perlu adanya pengadukan untuk meningkatkan aerasi di dalam sistem. Hasil fermentasi pada umumnya akan berbau seperti tape, ukuran dan bentuk bahan sudah berubah dari morfologi awal. Dibandingkan secara aeraob, fermentasi atau digestasi secara anaerob menghasilkan POC dengan kandungan hara yang lebih tinggi (Mostafazadeh-Fard et al., 2019; Sasrto et al., 2013). Digestasi anaerob menghasilkan gas methan yang bersifat mudah terbakar sehingga harus disalurkan melalui selang yang berujung pada bejana berisi air.

Kisaran $\mathrm{pH}$ yang baik untuk pupuk organik adalah sekitar 6,5 - 7,5 (netral). Biasanya $\mathrm{pH}$ agak turun pada awal proses pengomposan karena aktivitas bakteri yang menghasilkan asam, dengan munculnya mikroba lain bahan yang di dekomposisikan, maka $\mathrm{pH}$ bahan akan naik setelah beberapa hari dan kemudian berada pada kondisi netral (Indriani, 2003).

Menurut Indriani (2004) dalam proses pembuatan pupuk organik sangat dipengaruhi oleh faktor berikut:

1. Nisbah $\mathrm{C} / \mathrm{N}$ : Proses pembuatan kompos akan menurunkan $\mathrm{C} / \mathrm{N}$ rasio sehingga menjadi 12-20 agar dapat dimanfaatkan oleh tanaman. Nisbah $\mathrm{C} / \mathrm{N}$ setiap bahan berbeda-beda, semakin tinggi nisbah $\mathrm{C} / \mathrm{N}$ maka proses fermentasi atau dekomposisi menjadi lebih lama. Jika nisbahnya sangat tinggi maka membutuhkan input Nitrogen lebih banyak untuk menyelesaikan dekomposisi.
2. Ukuran bahan: bahan dengan ukuran yang lebih kecil memudahkan mikroba untuk mengurai dan mempercepat proses dekomposisi.

3. Jumlah mikroba: Selama proses fermentasi terjadi dinamika populasi bakteri selama masa fermentasi. Agens yang berperan dalam proses dekomposisi meliputi kelompok bakteri, jamur maupun actinomycetes. Populasi mikroba juga dapat ditingkatkan dengan penambahan mikroba fungsional atau starter untuk meningkatkan kualitas pupuk.

4. Suhu: hasil samping dari proses fermentasi oleh mikroba antara lain $\mathrm{CO}_{2}$, uap air, dan panas, sehingga perlu adanya selang untuk mengalirkan hasil samping ke lingkungan luar atau penampung yang berisi air, sehingga suhu di dalam fermentor menjadi relatif stabil.

\section{PENINGKATAN KUALITAS POC}

Persyaratan teknis minimal POC yang diatur dalam Kepmen Pertanian No 261/KPTS/SR.310/M/4/2019 adalah kandungan $\mathrm{C}$ organik minimal $10 \%(\mathrm{w} / \mathrm{v})$, hara makro $\mathrm{N}+\mathrm{P} 2 \mathrm{O} 5+\mathrm{K} 2 \mathrm{O} 2-6 \%$ (w/v), $\mathrm{N}$ organik minimum $0,5 \%$ (w/v), hara mikro Fe total $90-900 \mathrm{ppm}, \mathrm{Mn}$ total $25-500 \mathrm{ppm}, \mathrm{Cu}$ total 25-500 ppm, Zn total 25-500 ppm, B total 12-250 ppm, Mo total 2-10 ppm, pH 49, kandungan maksimum logam berat As 5,0 ppm, Hg 0,2 ppm, Pb 5,0 ppm, Cd 1,0 ppm, Cr 40 ppm, dan Ni 10 ppm. Persyaratan teknis tersebut menjadi acuan bagi industri pembuatan POC.

Menurut Suriadikarta dan Setyorini (2006) mutu kandungan hara POC antara lain bergantung dari sumber bahan baku dan proses fermentasinya. Bahan utama POC adalah dari feces dan urine hewan ternak terutama sapi dan kambing, limbah air kendang ternak, limbah air pengolahan hasil pertanian dan perikanan yang diharapkan memiliki kandungan hara makro terutama NPK yang tinggi (Tabel 1). Diba et al. 
(2013) melaporkan penggunaan feces kelelawar sangat penting untuk meningkatkan kandungan hara NPK terutama $\mathrm{P}$.

Urine kambing, domba, dan sapi umum digunakan petani untuk membuat POC karena kandungan unsur hara yang tinggi. Bioefikasi urine selain untuk meningkatkan pertumbuhan tanaman juga memperbaiki sifat fisik, kimia dan populasi mikrobia tanah, dan mengendalikan hama tanaman (Prandhan et al., 2018).

Tabel 1. Alternatif pilihan bahan utama pembuatan POC

\begin{tabular}{|c|c|c|}
\hline Bahan utama & Kandungan hara & Referensi \\
\hline Feces sapi & $0,53-0,65 \% \mathrm{~N} ; 0,15-0,35 \% \mathrm{P}, 0,3-0,41 \% \mathrm{~K}$ & Setyorini et al. (2006) \\
\hline Urine sapi & $\begin{array}{l}0,88 \% \mathrm{~N} ; 390 \text { ppm P; } 1,04 \% \mathrm{~K} ; 1185 \text { ppm } \\
\mathrm{Ca}, 147 \mathrm{ppm} \mathrm{Mg}, 0,081 \% \mathrm{~S}\end{array}$ & Saunders (1982) \\
\hline Feces kambing & $\begin{array}{l}1,28 \mathrm{~N} ; 0,19 \mathrm{P} ; 0,93 \mathrm{~K}, 0,59 \% \mathrm{Ca}, 0,19 \% \\
\mathrm{Mg}\end{array}$ & Setyorini et al. (2006) \\
\hline Urine kambing & $\begin{array}{l}\text { N } 1,7 \%, \text { P } 0,003 \%, \mathrm{~K} 1,45 \%, \text { Ca } 0,014 \% \text {, } \\
\text { Mg } 0,04 \%\end{array}$ & Ogejo et al. (2010) \\
\hline Urine domba & $\begin{array}{l}\text { N 2,2\%, P } 0,005 \%, \text { K 2,4\%, Ca } 0,009 \% \text {, } \\
\text { Mg } 0,08 \%\end{array}$ & Ogejo et al. (2010) \\
\hline Feces kelelawar & N 7-17\%, P 8-15\%, K 1,5-2,5\% & Diba et al. (2013) \\
\hline Limbah air industri tahu & $\begin{array}{l}\text { Gula } 13,59 \mathrm{~g} / \mathrm{l} \text {, protein } 1,24 \mathrm{~g} / \mathrm{l}, \mathrm{N} \text { total } \\
753,5 \mathrm{mg} / \mathrm{l}, \mathrm{P} \text { total } 103,5 \mathrm{mg} / \mathrm{l}\end{array}$ & Fang et al. (2019) \\
\hline Limbah air industri tempe & $\mathrm{N} 0,05 \%, \mathrm{P} 0,048 \%, \mathrm{~K} 0,02 \%$ & Diba et al. (2013) \\
\hline Limbah air industri tapioka & $\begin{array}{l}\mathrm{N} 3,06 \mathrm{~g} / \mathrm{l}, \mathrm{P} 0,31 \mathrm{~g} / \mathrm{l}, \mathrm{K} 3,2 \mathrm{~g} / \mathrm{l}, \mathrm{Ca} 0,24 \mathrm{~g} / \mathrm{l}, \\
\mathrm{Mg} 1,59 \mathrm{~g} / 1, \mathrm{Na} 0,39 \mathrm{~g} / 1\end{array}$ & Dantas et al. (2014) \\
\hline Limbah air kandang sapi & $\begin{array}{l}\mathrm{C} \text { organik } 34 \%, \mathrm{~N} \text { total } 0,23 \% \text {, total } \mathrm{P} \\
0,13 \% \mathrm{C} / \mathrm{N} 14,5\end{array}$ & Li et al. (2016) \\
\hline Limbah air kandang babi & $\begin{array}{l}\text { N 2,25-3,1 g/l, P 2,58-3,41 g/l, K 1,07-1,31 } \\
\text { g/l, Mn 0,03-0,04 g/l, Cu 0,06-0,08 g/l }\end{array}$ & Antoneli et al. (2019) \\
\hline Hidrolisis limbah ikan & N $1,65 \%$, P $0,18 \%$, K $0,27 \%$ & Basmal (2010) \\
\hline
\end{tabular}

Untuk lebih meningkatkan kandungan unsur hara dalam POC maka dalam bahan baku ditambahkan cacahan tumbuhan berupa brangkasan atau pangkasan tumbuhan yang tersedia di lokasi. Cacahan terutama dari famili legum, gulma, atau hijauan yang diketahui memiliki kandungan hara $\mathrm{N}$ atau protein serta unsur makro lainnya yang tinggi (Tabel 2). Hijauan sumber $\mathrm{N}$ atau protein tersebut banyak tersedia di pedesaaan sehingga perlu dimanfaatkan untuk meningkatkan mutu POC. Tumbuhan lainnya seperti Azolla microphylla merupakan salah satu jenis paku air penghasil biomassa (Al Arif et al., 2021) yang mempunyai kualitas nutrisi yang tinggi terutama nitrogen.
Limbah panen perkebunan seperti kulit kopi dan kakao belum banyak dimanfaatkan bahkan hanya dibiarkan mengering kemudian dibakar, dibuat biochar (Hanisah et al., 2020) atau dibuat kompos (Minarsih et al., 2013). Kulit kopi (skin, pulp, parchment) mengandung karbohidrat $(35 \%)$, protein $(5,2 \%)$, fiber $(30,8 \%)$ dan mineral $(10,7 \%)$ ( Prihantoro dan Emanauli, 2018). Sebagai sumber hara K, Ca, dan Mg dapat ditambahkan abu hasil pembakaran limbah pertanian di akhir proses fermentasi seperti dilaporkan oleh Maulinda dan Jalaluddin (2012). Abu sabut kelapa, abu tandan kosong kelapa sawit dan abu kayu mengandung hara $\mathrm{K}$ dan $\mathrm{Ca}$ yang tinggi. 
Tabel 2. Bahan alternatif pengaya unsur hara POC

\begin{tabular}{lllllll}
\hline Bahan pengaya unsur hara & $\mathrm{N}(\mathrm{CP})$ & $\mathrm{P}$ & $\mathrm{K}$ & $\mathrm{Ca}$ & $\mathrm{Mg}$ & $\mathrm{Ref}$ \\
\hline Brangkas Kacang tanah & 4,59 & 0,25 & 2,03 & 1,24 & 0,37 & 6 \\
Brangkas Kedelai & 5,55 & 0,34 & 2,41 & 0,88 & 0,37 & 6 \\
Brangkas Kentang & 3,25 & 0,2 & 7,5 & 0,43 & 0,2 & 6 \\
Brangkas ubi jalar & 3,76 & 0,38 & 4,01 & 0,78 & 0,68 & 6 \\
Koro benguk & 2,2 & 0,3 & 1,3 & 3,8 & 0,5 & 1 \\
Arachis pintoi & 1,7 & 0,3 & 2,8 & 2,2 & 0,4 & 1 \\
Calopogonium caeruleum & 2,9 & 0,2 & 2,7 & 1,9 & 0,3 & 1 \\
Flemingia & $2,9-3,0$ & $0,2-0,4$ & $0,5-1,3$ & 1,6 & 0,41 & 1 \\
Glirisidia & $2,4-3,7$ & 0,2 & $0,9-2,2$ & $1,9-3,2$ & $0,5-0,8$ & 1 \\
Lamtoro gung & $2,6-4,1$ & $0,1-0,2$ & $0,5-0,6$ & $0,9-1,8$ & $0,4-0,5$ & 1 \\
Kaliandra & $2,6-4,1$ & $0,1-0,2$ & $0,5-0,6$ & $0,9-1,8$ & $0,4-0,5$ & 1 \\
Tithonia & $2,5-3,5$ & $0,25-0,38$ & $2,5-4.1$ & 0,25 & & 2 \\
Krinyu & $1,8-2,9$ & $0,13-0,50$ & $1,01-2,60$ & & & 3 \\
Badotan & $(24,5)$ & 0,38 & 0,139 & 0,22 & 0,11 & 4 \\
Asystasia gangetica & $(15,5-25)$ & $1,1-1,7$ & & $1,8-2,0$ & $0,68-0,85$ & 12 \\
Daun tebu & 1,12 & 0,08 & 2,45 & & & 11 \\
Azolla & $1,96-5,30$ & $0,16-1,59$ & $0,31-5,97$ & $0,45-1,70$ & $0,22-0,66$ & 1 \\
Kulit buah kakao & 0,91 & 0,2 & 3,18 & 0,67 & 0,29 & 5 \\
Pulp kulit kopi & 1,91 & 0,28 & 3,61 & & & 5 \\
Abu kulit kopi & 0 & 1,03 & 5,29 & 0,76 & 0,38 & 5 \\
Abu Jerami padi & 0,6 & 0,09 & 1,08 & & & 8 \\
Abu sekam padi & 0 & $0,32-0,46$ & $1,15-1,50$ & $0,35-0,71$ & $0,12-0,30$ & 7 \\
Abu sabut & 0 & 0,27 & 19,85 & 27,93 & & 10 \\
Abu kayu & 0 & $0,3-1,4$ & $3-4 \%$ & $7-33 \%$ & $1-2 \%$ & 9 \\
Abu tankos sawit & 0 & $4 \%$ & $30 \%$ & $5 \%$ & $6 \%$ & 13 \\
\hline Ketangan & 0 & & & & \\
\end{tabular}

Keterangan: 1 = Rachaman et al. (2006), 2 = Hakim et al. (2012), 3 = Nugroho et al. (2019), 4 = Abiodun et al. (2020), 5 = PT Perkebunan XXVI (1991), 6=Setyorini et al. (2006), 7 = Hashim et al . (1996), 8 = Makarim et al. (2007), 9 = Siddique (2008), $10=$ Anuar et al. (2018), $11=$ Phibunwatthanawong \& Riddech (2019), 12 = Khalil et al. (2018), $13=$ Othman et al. (2005)

Penambahan dekomposer komersial maupun mikro organisme lokal (MOL) akan meningkatkan proses dan mutu POC yang dihasilkan yaitu meningkatkan kandungan hara maupun mengurangi bau. Limbah buah seperti papaya, tomat, pisang dan limbah sayur seperti kubis dan wortel sering ditambahkan sebagai sumber MOL dan sumber energi bagi perkembangan MOL. Sumber energi bagi perkembangan dekomposer yang tersedia di lokasi pedesaan misalnya air nira, dan gula kelapa atau aren. Sedangkan rempah dan empon-empon ditambahkan sebagai sumber MOL yang efektif mengurangi baru POC yang dihasilkan seperti yang dilaporkan oleh
Nuraini dan Asgianingrum (2017) serta Heryadi (2013).

Buah dari tumbuhan yang belum banyak dimanfaatkan kecuali sebagai obat tradisional seperti mengkudu (Evizal et al., 2013), beligo, dan berenuk merupakan sumber pulp dan umumnya tersedia di desa. Limbah dapur seperti air cucian beras dan sisa nasi tersedia di rumah tangga sehingga dapat dimanfaatkan untuk sumber energi dekomposer. Mostafazadeh-Fard et al. (2019) melaporkan penambahan molases pada pembuatan POC meningkatkan kandungan hara NPK dalam POC yang dihasilkan. 
Tabel 3. Bahan alternatif pengaya fermantasi POC

\begin{tabular}{|c|c|c|}
\hline $\begin{array}{l}\text { Pengaya } \\
\text { fermentasi }\end{array}$ & Kandungan & Referensi \\
\hline Wortel & $\begin{array}{l}\text { Protein } 0.7 \% \text {, lemak } 0.5 \% \text {, Karbohidrat } 6 \% \text {, total gula } \\
5.6 \% \text {, serat kasar } 2.4 \%, \mathrm{Ca}(34 \mathrm{mg} / 100 \mathrm{~g}, \mathrm{Fe} 0.4 \mathrm{mg} / 100 \\
\mathrm{g}, \mathrm{P} 25 \mathrm{mg} / 100 \mathrm{~g}, \mathrm{Na} 40 \mathrm{mg} / 100 \mathrm{~g}, \mathrm{~K} 240 \mathrm{mg} / 100 \mathrm{~g}, \mathrm{Mg} \\
9 \mathrm{mg} / 100 \mathrm{~g}, \mathrm{Cu} 0.02 \mathrm{mg} / 100 \mathrm{~g}, \mathrm{Zn} 0,2 \mathrm{mg} / 100 \mathrm{~g} \text {, } \\
\text { karoten } 5,33 \mathrm{mg} / 100 \mathrm{~g}, \text { tiamin } 0,04 \mathrm{mg} / 100 \mathrm{~g} \text {, riboflavin } \\
0,02 \mathrm{mg} / 100 \mathrm{~g} \text {, niacin } 0,2 \mathrm{mg} / 100 \mathrm{~g} \text {, vitamin C } 4 \mathrm{mg} / 100 \\
\text { g) energi } 126 \mathrm{~kJ} / 100 \mathrm{~g}\end{array}$ & Sharma et al. (2012) \\
\hline Kubis & $\begin{array}{l}\text { Karbohidrat } 3,76-6,78 \% \text {, lemak } 0,16-0,25 \% \text {, protein } \\
1,04-1,59 \%\end{array}$ & $\begin{array}{l}\text { Adelanwa \& Medugu } \\
(2015)\end{array}$ \\
\hline Tomat & $\begin{array}{l}\text { Karbohidrat } 4,2 \mathrm{~g} / 100 \mathrm{~g} \text {, protein } 1 \mathrm{~g} \text {, lemak } 0,3 \mathrm{~g} \text {, fosfor } \\
27 \mathrm{mg} \text {, kalsium } 5 \mathrm{mg} \text {, zat besi } 0,5 \mathrm{mg}\end{array}$ & $\begin{array}{l}\text { Rahmadina \& Putri } \\
\text { (2019) }\end{array}$ \\
\hline Pepaya & $\begin{array}{l}\text { Per } 100 \mathrm{~g} \text { mengandung } 0,5 \mathrm{~g} \text { protein, } 0,3 \mathrm{~g} \text { lemak, } 12,1 \\
\mathrm{~g} \text { karbohidrat, } 0,7 \mathrm{~g} \text { serat, } 0,5 \mathrm{~g} \text { abu, } 204 \mathrm{mg} \text { kalium, } 34 \\
\mathrm{mg} \text { kalsium, } 11 \mathrm{mg} \text { fosfor, } 1 \mathrm{mg} \text { besi, } 74 \mathrm{mg} \text { vitamin } \mathrm{A} \text {, } \\
0,003 \mathrm{mg} \text { tiamin, } 0,5 \mathrm{mg} \text { niasin, dan } 0,004 \text { riboflavin. }\end{array}$ & $\begin{array}{l}\text { Fatria \& } \\
\text { Noflindawati (2014) }\end{array}$ \\
\hline Pulp pisang & $\begin{array}{l}\text { Karbohidrat } 16.72-35.24 \mathrm{~g} 100 \mathrm{~g}-1 \text {, total gula } 12.12- \\
20.82 \mathrm{~g} 100 \mathrm{~g}-1 \text {, vitamin C } 16.45-30.27 \mathrm{~g} 100 \mathrm{~g}-1 \text {, Kalium } \\
275-375 \mathrm{~g} 100 \mathrm{~g}-1 \text {, protein } 1.48-1.78 \mathrm{~g} 100 \mathrm{~g}-1 \text {, lemak } \\
0.03-0.08 \mathrm{~g} 100 \mathrm{~g}-1 \text {. Dalam } 100 \mathrm{~g} \text { porsi buah yang } \\
\text { dimakan terdapat } 73.43-148.80 \text { calories. }\end{array}$ & $\begin{array}{l}\text { Hapsari \& Lestari } \\
(2016)\end{array}$ \\
\hline Pulp beligo & $\begin{array}{l}\text { Protein kasar } 0,49 \% \text {, karbohidrat } 3,36 \% \text {, serat kasar } \\
0,32 \% \text {, lemak } 0,6 \% \text {, alkaloid } 4,35 \% \text {, flavonoid } 0,95 \% \text {, } \\
\text { tannin } 0,07 \% \text {, phytate } 0,06 \%\end{array}$ & Ekeke et al. (2019) \\
\hline Pulp mengkudu & $\begin{array}{l}\text { Gula total } 20,1 \% \text {, asetat } 0,04(\mathrm{~g} / \mathrm{l}) \text {, klorida } 1,14(\mathrm{~g} / \mathrm{l}) \text {, } \\
\text { sitrat } 0,03(\mathrm{~g} / \mathrm{l}) \text {, malat } 4,64(\mathrm{~g} / \mathrm{l}) \text {, oksalat } 0,75(\mathrm{~g} / \mathrm{l}) \text {, fosfat } \\
0,5(\mathrm{~g} / \mathrm{l}) \text {, sulfat } 0,45(\mathrm{~g} / \mathrm{l}), \mathrm{N} 3,64 \%, \mathrm{P} 0,25 \%, \mathrm{~K} 4,01 \% \text {, } \\
\text { Ca } 0,29 \%, \mathrm{Mg} 0,14 \%, \mathrm{~S} 0,3 \%, \mathrm{Na} 0,22 \%\end{array}$ & $\begin{array}{l}\text { Chunhieng et al. } \\
\text { (2005) }\end{array}$ \\
\hline Pulp berenuk & $\begin{array}{l}\text { Karbohidrat } 18,61 \% \text {, lemak } 1,13 \% \text {, protein kasar } \\
8,38 \% \text {, serat kasar } 4,29 \%\end{array}$ & Ejelonu et al. (2011) \\
\hline Air kelapa & $\begin{array}{l}\mathrm{Na}(20,55 \mathrm{mg} / 100 \mathrm{ml}), \mathrm{Ca}(26,50 \mathrm{mg} / 100 \mathrm{ml}), \mathrm{Mg}(7,52 \\
\mathrm{mg} / 100 \mathrm{~m}), \mathrm{Fe}(0,32 \mathrm{mg} / 100 \mathrm{ml}), \mathrm{P}(12,50 \mathrm{mg} / 100 \mathrm{ml}) \\
\text { dan K }(15,37 \mathrm{mg} / 100 \mathrm{ml}\end{array}$ & Fahlei et al. (2017) \\
\hline Nira kelapa & $\begin{array}{l}\text { Gula total 9,3 g/100ml, protein } 13,3 \mathrm{mg} \text {, lemak } 0,03 \mathrm{~g} \text {, } \\
\mathrm{Ca} 1,62 \mathrm{mg}, \mathrm{Mg} 2,15 \mathrm{mg}, \mathrm{Fe} 1,2 \mathrm{mg}, \mathrm{Na} 6,95 \mathrm{mg}, \mathrm{K} \\
3,16 \mathrm{mg}, \mathrm{Cu} 0,03 \mathrm{mg}, \mathrm{Zn} 0,03 \mathrm{mg}, \mathrm{P} 1,55 \mathrm{mg} \text { per } 100 \mathrm{~g}\end{array}$ & $\begin{array}{l}\text { Barh \& Mazumdar } \\
(2008)\end{array}$ \\
\hline Nira at & Gula $12,04 \%$, protein $0,36 \%$, lemak $0,02 \%$, & ni (2016) \\
\hline Gula aren & $\begin{array}{l}\text { Gula total } 77,56 \% \text {, karbohidrat } 88,45 \% \text {, protein } 2,03 \% \text {, } \\
\text { lemak } 0,37 \%\end{array}$ & Heryani (2016) \\
\hline Limb & N 0,015\%, P 0,14\%, K 0,02\%, Ca 0,294\%, Mg 1,42\% & \\
\hline Limbah nasi & $\begin{array}{l}\text { Karbohidrat } 34-39 \mathrm{~g} / 100 \mathrm{~g} \text {, protein } 3 \mathrm{~g} / 100 \mathrm{~g} \text {, Ca } 25 \\
\mathrm{mg} / 100 \mathrm{~g}, \text { P } 27 \mathrm{mg} / 100 \mathrm{~g}, \mathrm{~K} 38 \mathrm{mg} / 100 \mathrm{~g}\end{array}$ & Mukti et al (2018) \\
\hline $\begin{array}{l}\text { Lengkuas, } \\
\text { kencur, kunyit, } \\
\text { temulawak, jahe }\end{array}$ & Minyak atsiri, mengurangi bau & $\begin{array}{l}\text { Nuraini \& } \\
\text { Asgianingrum (2017) }\end{array}$ \\
\hline Serai & Minyak atsiri, mengurangi bau & \\
\hline Molases & $\begin{array}{l}\text { N } 0,92 \%, \text { P } 0,04 \% \text {, K } 5,25 \% \text {, C org } 43,77 \% \text {, gula } 50- \\
65 \%\end{array}$ & $\begin{array}{l}\text { Phibunwatthanawong } \\
\& \text { Riddech (2019), } \\
\text { Rochani et al (2015) }\end{array}$ \\
\hline
\end{tabular}




\section{APLIKASI PUPUK ORGANIK CAIR}

Beberapa penelitian menjelaskan bahwa POC dapat menjadi alternatif atau pupuk tambahan dalam proses budidaya yang diujikan pada berbagai komoditas terutama palawija atau hortikultura. Tanaman hortikultura cenderung menghasilkan respon yang lebih cepat terhadap aplikasi POC. Pupuk organik cair hasil fermentasi tanpa penambahan bahan pengaya unsur hara dilaporkan dapat meningkatkan pertumbuhan atau hasil tanaman misalnya aplikasi POC dari urine sapi dan limbah air tahu telah dilaporkan Desiana et al. (2013) dan aplikasi bio-slurry cair telah yang dilaporkan Edy et al. (2021).

Hasil Penelitian Wahyudi et al. (2019) menjelaskan bahwa pupuk organik cair berbahan bonggol pisang dengan konsentrasi $15 \%$ memberikan pengaruh terhadap tinggi tanaman pada 6 minggu setelah tanam (MST) dan jumlah polong kacang tanah mencapai 48,94 polong. Hasil Penelitian Chaniago et al. (2017) juga menjelaskan bahwa pemberian POC Bonggol pisang $20 \mathrm{ml} / \mathrm{L}$ menghasilkan produksi kacang hijau per plot lebih tinggi dibandingkan dengan dosis $10 \mathrm{ml} / \mathrm{L}$ dan 0 $\mathrm{ml} / \mathrm{L}$.

Suhastyo et al. (2013) menyatakan bahwa bonggol pisang mengandung senyawa karbohidrat (66\%), protein, air, dan mineral-mineral penting. Bonggol pisang mempunyai kandungan pati $45,4 \%$ dan kadar protein $4,35 \%$. Bonggol pisang mengandung mikroba pengurai bahan organik antara lain kelompok Bacillus sp, Aeromonas sp, dan Aspergillus nigger. Mikroba tersebut bertindak sebagai agens pengurai bahan atau substrat organik.

Selain Bonggol pisang, urine sapi juga dapat dimanfaatkan sebagai pupuk organik cair. Pemanfaatan pupuk cair urine sapi memberikan pengaruh nyata terhadap pertumbuhan dan produksi tanaman jagung manis dengan dosis $7 \mathrm{ml} / \mathrm{l}(7.000 \mathrm{ppm})$ pada waktu aplikasi 2, 4, 6 dan 8 MST serta direkomendasikan sebagai sebagai pupuk alternatif Urea (Pangaribuan dan Kurniawan, 2017). Menurut penelitian Azisah (2017) bahwa pemberian pupuk organik cair urine sapi dengan dosis 300 $\mathrm{mL} / \mathrm{L}$ mampu memberikan hasil tertinggi pada pertumbuhan dan produksi tanaman terong dengan interval waktu untuk pemberian setiap 1 minggu. Percobaan pada tanaman jagung, kombinasi konsentrasi pupuk organik cair $2 \mathrm{~mL} / \mathrm{L}$ dengan $1 / 2$ dosis reomendasi pupuk $\mathrm{N}, \mathrm{P}, \mathrm{K}$ mampu memberikan pengaruh yang lebih baik terhadap pertumbuhan dan hasil tanaman jagung manis. Pemberian POC juga berpengaruh terhadap produktivitas yang setara dengan pemberian 1 dosis pupuk $\mathrm{N}, \mathrm{P}$, $\mathrm{K}$ yaitu sebesar 17,46 ton/ha (Puspadewi et al., 2016).

\section{KESIMPULAN}

Penurunan kualitas tanah atau degradasi lahan disebabkan karena praktik pertanian intensif yang menggunakan agrokimia sintetik secara terus menerus. Upaya perbaikan yang dapat dilakukan yaitu dengan pemanfaatan POC. Salah satu keunggulan POC adalah unsur hara sudah terlarut sehingga lebih cepat diserap tanaman daripada pupuk organik padat. Seiring dengan peningkatan permintaan produk hortikultura organik maka kebutuhan POC semakin meningkat. Untuk meningkatkan kualitas POC maka perlu dipilih bahan-bahan yang mengandung unsur hara yang tinggi terutama unsur hara makro, Selain itu perlu ditambahkan starter dan bahan pendorong pertumbuhan dekomposer. Pemanfaatan POC sudah sering diuji pada berbagai komoditas dan menunjukkan hasil positif untuk meningkatkan pertumbuhan tanaman dan memperbaiki sifat-sifat tanah. 


\section{DAFTAR PUSTAKA}

Abiodun, D.J., A.E. Mark, A.M. Umar, O.G. Wilson, and N.R. Olufunke. 2020. Nutritional composition and antioxidant analyses of Ageratum conyzoides Whole Plant. International Journal of Scientific and Research Publications, 10(8): 922928.

Adelanwa, E. B. and J.M. Medugu. 2015. Variation in the nutrient composition of red and green cabbage (Brassica oleracea) with respect to age at harvest. Journal of Applied Agricultural Research, 7: 183189.

Al Arif, F., H. Susanto, dan H. Pujisiswanto. 2021. Pengaruh pupuk kandang kambing dan sapi terhadap pertumbuhan Azolla microphylla. Jurnal Agrotropika, 20(1): 35-41.

Ameeta, S. and C. Ronak. 2017. A review on the effect of organic and chemical fertilizers on plants. International Journal for Research in Applied Science and Engineering Technology, 5(2): 677-680.

Antoneli, V., A.C. Mosele, J.A. Bednarz, M. Pulido-Fernández, J. Lozano-Parra, S.D. Keesstra, and J. Rodrigo-Comino. 2019. Effects of applying liquid swine manure on soil quality and yield production in tropical soybean crops (Parana, Brazil). Sustainability, 11(14): 3898.

Anuar, M.F., Y. W. Fen, M.H.M. Zaid, K.A. Matori, and R.E.M. Khaidir. 2018. Synthesis and structural properties of coconut husk as potential silica source. Results in Physics, 11: 1-4.

Azisah, A. 2017. Pengaruh pemberian pupuk organik cair urine sapi terhadap pertumbuhan dan produksi tanaman terong (Solanum melongena L.). Jurnal Agrotan, 3(2): 80-91.

Barh, D. and B.C. Mazumdar. 2008. Comparative nutritive values of palm saps before and after their partial fermentation and effective use of wild date (Phoenix sylvestris Roxb.) sap in treatment of anemia. Research Journal of Medicine and Medical Sciences, 3(2): 173-176.
Basmal, J. 2010. Teknologi pembuatan pupuk organik cair kombinasi hidrolisat rumput laut Sargassum sp. dan limbah ikan. Squalen, 5(2): 59-66.

Chaniago, N., D.W. Purba, dan A. Utama. 2017. Respon pemberian pupuk organik cair (POC) bonggol pisang dan sistem jarak tanam terhadap pertumbuhan dan produksi kacang hijau (Vigna Radiata L. Willczek). Bernas: Jurnal Penelitian Pertanian, 13(2): 1-8.

Chunhieng, T., L. Hay, and D. Montet. 2005. Detailed study of the juice composition of noni (Morinda citrifolia) fruits from Cambodia. Fruits, 60(1): 13-24.

Dantas, M.S.M., M. M. Rolim, A. de S. Duarte, E.F.D.F.D. Silva, E.M.R. Pedrosa, and D.D.C. Dantas. 2014. Chemical attributes of soil fertilized with cassava mill wastewater and cultivated with sunflower. The Scientific World Journal, 2014(279312): 1-10.

Darwis, V. 2014. Subsidi pupuk: Kebijakan, pelaksanaan, dan optimalisasi pemanfaatannya. Analisis Kebijakan Pertanian, 11(1): 45-60.

Desiana, C., I.S. Banuwa, R. Evizal, dan S. Yusnaini. 2013. Pengaruh pupuk organik cair urin sapi dan limbah tahu terhadap pertumbuhan bibit kakao (Theobroma cacao L). Jurnal Agrotek Tropika, 1(1): 113-119.

Diba, P.F., E.B. Susatyo, dan W. Pratjojo. 2013. Peningkatan kadar N, P dan K pada pupuk organik cair dengan pemanfaatan bat guano. Indo. J. Chem. Sci. 2(1): 56-60.

Edy, A., R.P.K. Sari, dan H. Pujisiswanto. 2021. Pengaruh dosis pupuk organik bio-Slurry cair dan waktu aplikasi terhadap pertumbuhan dan hasil tanaman jagung (Zea Mays L.). Jurnal Agrotropika, 20(1): 17-27.

Ejelonu, B.C., A.A. Lasisi, A.G. Olaremu, and O.C. Ejelonu. 2011. The chemical constituents of calabash (Crescentia cujete). African Journal of Biotechnology, 10(84): 19631-19636.

Ekeke, C., C.A. Ogazie, and I.O. Agbagwa. 2019. Anatomical and phytochemical 
studies on Benincasa hispida (Thunb.) Cogn. (Cucurbitaceae). Notulae Scientia Biologicae, 11(1): 102-111.

Evizal, R., E. Setyaningrum, A. Wibawa and D. Aprilani. 2013. Keragaman tumbuhan dan ramuan etnomedisin Lampung Timur. Prosiding Semirata Bidang Ilmu MIPA PTN BKS Barat. p 279-286.

Fahlei, R., E. Rahayu dan V. Kautsar. 2017. Pengaruh pemberian air kelapa dan limbah cair ampas tahu pada tanah Regusol terhadap pertumbuhan bibit kelapa sawit di prenursery. Jurnal Agromast, 2(1): 1-13.

Fang, C., J. He, V. Achal, and G. Plaza. 2019. Tofu wastewater as efficient nutritional source in biocementation for improved mechanical strength of cement mortars. Geomicrobiology Journal, 36(6): 515521.

Fatmawati, I. 2010. Uji Efektivitas pupuk cair urine sapi sebagai substitusi pupuk Urea terhadap pertumbuhan dan hasil tanaman padi (Oryza sativa). Jurnal Pertanian Cemara, 7 (1): 34-40.

Febrianna, M., S. Prijono, dan N. Kusumarini. 2018. Pemanfaatan pupuk organik cair untuk meningkatkan serapan nitrogen serta pertumbuhan dan produksi sawi (Brassica juncea L.) pada tanah berpasir. Jurnal Tanah dan Sumberdaya Lahan, 5(2): 1009-1018.

Fatria, D. dan Noflindawati. 2014. Karakterisasi kualitas buah empat genotip pepaya (Carica papaya L.) koleksi Balai Penelitian Tanaman Buah Tropika. J. Floratek, 9: 1-5.

Fitria, Y., B. Ibrahim, dan D. Desniar. 2008. Pembuatan pupuk organik cair dari limbah cair industri perikanan menggunakan asam asetat dan EM4 (Effective Microorganisme 4). Akuatik: Jurnal Sumberdaya Perairan: 2(1): 2326.

Hadisuwito, S. 2007. Membuat Pupuk Kompos Cair. AgroMedia.

Hakim, N., Agustian, and Y. Mala. 2012. Application of Organic Fertilizer Tithonia Plus to Control Iron Toxicity and Reduce
Commercial Fertilizer Application on New Paddy Field. J. Trop. Soils, 17(2): 135-142.

Hanifa, A., dan L. Lutojo. 2014. Penggunaan pupuk organik berbahan urine sapi terhadap kualitas kimia tanah di Lereng Merapi. Buana Sains, 14(2): 157-163.

Hanisah, R. Evizal, F. Yelli, dan Sugiatno. 2020. Pengaruh formulasi biochar dan limbah kulit kopi terhadap pertumbuhan bibit kopi. Jurnal Agrotropika, 9(2): 102-109.

Hapsari, L. and D.A. Lestari. 2016. Fruit characteristic and nutrient values of four Indonesian banana cultivars (Musa spp.) at different genomic groups. Agrivita Journal of Agricultural Science, 38(3): 303-311.

Hapsari, N. dan T. Welasih. 2013. Pemanfaatan limbah ikan menjadi pupuk organik. Jurnal Teknik Lingkungan, 2(1): 1-6.

Hartati, S., S. Sumani dan H.E. Hendrata. 2014. Pengaruh imbangan pupuk organik dan anorganik terhadap serapan $\mathrm{P}$ dan hasil tanaman padi sawah pada dua sistem budidaya di lahan sawah Sukoharjo. Caraka Tani: Journal of Sustainable Agriculture, 29(1): 53-60.

Hashim, A.B., H. Aminuddin, K.B. Siva, and Mardi. 1996. Nutrient content in rice Husk ash of some Malaysian Rice Varieties. Pertanika J. Trop. Agric. Sci. 19(1): 7780.

Hendriyatno, F., D. Okalia, dan M. Mashadi. 2019. Pengaruh pemberian POC urine sapi terhadap pertumbuhan bibit pinang betara (Areca Catechu L.). Agro Bali: Agricultural Journal, 2(2): 89-97.

Heryadi, H. 2013. Pemanfaatan sereh (Cymbopogon cytratus) dalam menurunkan bau pada pupuk organik cair dan potensinya dalam meningkatkan produksi tanaman cabai (Capsicum annum). Jurnal Matematika, Sains, dan Teknologi, 14(1): 37-47.

Heryani, H. 2016. Keutaman Gula Aren \& Strategi Pengembangan Produk. Lambung Mangkurat Univ. Press. 158 p.

Hou, J., M. Li, X. Mao, Y. Hao, J. Ding, D. Liu, and H. Liu. 2017. Response of microbial 
community of organic-matterimpoverished arable soil to long-term application of soil conditioner derived from dynamic rapid fermentation of food waste. Plos One, 12(4).

Indriani, Y.H. 2004. Membuat Kompos Secara Kilat. Jakarta. Penebar Swadaya.

Indriani. 2003. Petunjuk Penggunaan Pupuk. Penebar Swadaya, Jakarta.

Khalil, K., S. Suyitman, and M. Montesqrit, 2018. Crude nutrient and mineral composition of Asystasia gangetica (L) derived from different growing areas. Proceeding The $4^{\text {th }}$ International Seminar on Animal Industry. p 189-192.

Li, Y., Q. Liu, F. Liu, P. Zhu, L. Zhang, X. Zhou, C. Sun, and Y. Cheng. 2016. Effects of different ratios of sewage sludge and cattle manure on growth and propagation of Eisenia fetida. Plos One, 11(6), p e0156492.

Makarim, A.K., Sumarno, dan Suyamto, 2007. Jerami Padi: Pengelolaan dan Pemanfaatan. Balai Penelitian dan Pengembangan Pertanian. Bogor.

Maulinda, L. dan Jalaluddin (2012). Pemanfaatan abu Jerami pada sebagai pembuatan pupuk kalium. Jurnal Teknologi Kimia Unimal, 1(1):12-22.

Maunte, Z., M. I. Jafar, dan M. Darmawan. 2018. Pengaruh pemberian pupuk organik cair ampas tahu dan bonggol pisang terhadap pertumbuhan dan produksi tanaman seledri (Apium graveolens L.). Agropolitan, 5(1): 70-76.

Minarsih, M.A.S. Arif, M.V. Rini, dan R. Evizal. 2013. Pengaruh pemberian kompos kulit buah kakao sebagai campuran media pembibitan dan pupuk NPK $(15: 15: 15)$ terhadap pertumbuhan bibit kakao (Theobroma cacao L.). Jurnal Agrotek Tropika, 1(2): 188-193.

Miner, G. L., J.A. Delgado, J. A. Ippolito, and C.E. Stewart, 2020. Soil health management practices and crop productivity Agricultural \& Environmental Letters, 5(1): 1-8.

Mostafazadeh-Fard, S., Z. Samani, and P. Bandini. 2019. Production of liquid organic fertilizer through anerobic digestation of grasses clippings. Waste and Biomass Valorization, 10: 771-781.

Mukti, K.S.A., N. Rohmawati, dan Sulistiyani. 2018. Analisis kandungan karbohidrat, glukosa, dan uji daya terima pada nasi bakar, nasi panggang, dan nasi biasa. Jurnal Agroteknologi, 12(1): 90-99.

Nugroho, B., W. Mildaryani, dan S.H.C. Dewi. 2019. Potensi gulma siam (Chromolaena odorata L.) sebagai bahan kompos untuk pengembangan bawang merah organik. $J$. Agron. Indonesia, 47(2): 180-187.

Nuraini, Y. dan R.E. Asgianingrum. 2017. Peningkatan kualitas biourin sapi dengan penambahan pupuk hayati dan molase serta pengaruhnya terhadap pertumbuhan dan produktivitas pakchoy. J. Hort. Indonesia, 8(3): 183-191.

Ogejo, J.A., S. Wildeus, P. Knight and R.B. Wilke. 2010. Estimating goat and sheep manure production and their nutrient contribution in the Chesapeake Bay watershed. Applied Enginering in Agriculture, 26(6): 1061-1065.

Othman, H., A.T. Mohammed, and M.T. Dolmat. 2005. Bunch ash: An efficient and cost-effective $\mathrm{K}$ fertilizer source for mature aoil palm on peat under higk rainfall environment. MPOB Information Series No 254, 5p.

Pangaribuan, D. H., dan C. Kurniawan. 2017. Pengaruh pupuk cair urine sapi terhadap pertumbuhan dan produksi tanaman jagung manis (Zea mays L.). Jurnal Metamorfosa, 4(2): 202-209.

Parman, S. 2007. Pengaruh pemberian pupuk organik cair terhadap pertumbuhan dan produksi kentang (Solanum tuberosum L.). Anatomi Fisiologi: 15(2): 21-31.

Phibunwatthanawong, T. and N. Riddech. 2019. Liquid organic fertilizer production for growing vegetables under hydroponic condition. International Journal of Recycling of Organic Waste in Agriculture, 8:369-380.

Pradhan, S.S., S. Verma, S. Kumari, and Y. Singh. 2018. Bio-efficacy of cow urine on crop production: A review. International 
Journal of Chemical Studies, 6(3): 298301

Priangga, R., Suwarno, dan N. Hidayat. 2013. Pengaruh level pupuk organik cair terhadap produksi bahan kering dan imbangan daun-batang rumput gajah defeliosi keempat. Jurnal Ilmiah Peternakan: 1(1), 365-373.

Prihantoro, R. and Emanauli. 2018. A study of tea production from Liberica green coffee skin in Tungkal, Jambi as a refreshing drink. Indonesian Food Science \& Technology Journal: 1(2): 65-69.

PT Perkebunan XXVI.1991. Pemanfaatan kulit buah kakao dan kopi pada pertanaman kakao dan kopi di PT Perkebunan XXVI. Makalah seminar Bioteknologi dan Lokakarya Biopolimer untuk Industri. PAU Bioteknologi IPB. Bogor. 10-11 Desember 1991.

Puspadewi, S., W. Sutari, dan K. Kusumiyati. 2016. Pengaruh konsentrasi pupuk organik cair (POC) dan dosis pupuk N, P, $\mathrm{K}$ terhadap pertumbuhan dan hasil tanaman jagung manis (Zea mays L. var Rugosa Bonaf) kultivar talenta. Kultivasi, 15(3): 208-216.

Rachaman, A., A. Dariah, dan D. Santoso. 2006. Pupuk hijau. Dalam Simanungkalit, R.D.M., D.A. Suriadikata, R. Saraswati, D. Setyorini, dan W. Hartatik. Pupuk Organik dan Pupuk Hayati. Balai Besar Litbang Sumberdaya Lahan Pertanian. Bogor. Hlm. 41-57.

Rahmad, R., A. Karim, N. La Nafie, and M. Jayadi, M. 2018. Synthesis of liquid organic fertilizer based on chicken manure using Biosca and fungus bioactivator Trichoderma harzianum. Jurnal Akta Kimia Indonesia, 11(2): 2841.

Rahmadina dan S. Putri. 2019. Pemanfaatan penggunaan pupuk organik cair wortel dalam meningkatkan produktivitas tanaman tomat (Lycopersicum esculentum Mill.). Klorofil: 3(2): 20-25.

Rizal, S. 2017. Pengaruh nutriasi yang diberikan terhadap pertumbuhan tanaman sawi pakcoy (Brassica rapa 1.) Yang ditanam secara hidroponik. Sainmatika: Jurnal
Ilmiah Matematika dan Ilmu Pengetahuan Alam, 14(1): 38-44.

Rochani, A., S. Yuniningsih dan Z. Ma'sum. 2015. Pengaruh konsentrasi gula larutan molases terhadap kadar etanol pada proses fermentasi. Jurnal Reka Buana, 1(1): 4348.

Saunders, W.H.M. 1982. Effects of cow urine and its major constituents on pasture properties. New Zealand journal of agricultural research, 25(1): 61-68.

Sastro, Y., B. Bakrie, and N.R. Sudolar. 2013. The effect of fermentation method, microbe inoculation and carbon source proportion on the quality of organic fertilizer made from liquid wastes of chicken slaughterhouse. J. Indonesian Trop. Anim. Agric. 38(4): 257-263.

Setyorini, D., R. Saraswati dan E.K. Anwar. 2006. Kompos. Dalam Simanungkalit, R.D.M., D.A. Suriadikata, R. Saraswati, D. Setyorini, dan W. Hartatik. Pupuk Organik dan Pupuk Hayati. Balai Besar Litbang Sumberdaya Lahan Pertanian. Bogor. p 11-40.

Sharma, K.D., S. Karki, N. S. Thakur and S. Attri. 2012. Chemical composition, functional properties and processing of carrot-a review. J. Food Sci. Technol. 49(1): 22-32.

Siddique, R. 2008. Waste Materials and ByProducts in Concrete. Springer, Berlin, Heidelberg. DOI: 10.1007/978-3-54074294-4_9.

Sihotang, R. H., D. Zulfita, dan A.M. Surojul. 2013. Pengaruh Pupuk Organik Cair Terhadap Pertumbuhan dan Hasil Kacang Hijau Pada Tanah Aluvial. Jurnal Sains Mahasiswa Pertanian, 2(1): 1-10.

Solihin, E., A. Yuniarti, and M. Damayani. 2019. Application of liquid organic fertilizer and $\mathrm{N}, \mathrm{P}, \mathrm{K}$ to the properties of soil chemicals and growth of rice plant. IOP Conference Series: Earth and Environmental Science, 393(1): 012026.

Suhastyo, A.A., I. Anas, D.A. Santosa, dan Y. Lestari. 2013. Studi mikrobiologi dan sifat kimia mikroorganisme lokal (MOL) yang digunakan pada budidaya padi metode 
SRI (System of Rice Intensification). Sainteks, 10(2): 29-39.

Suprihatin. 2010. Teknologi Fermentasi. Unesa Press. Jakarta.

Suriadikarta, D.A. dan D. Setyorini. 2006. Baku mutu pupuk organik. Dalam Simanungkalit, R.D.M., D.A. Suriadikata, R. Saraswati, D. Setyorini, dan W. Hartatik. Pupuk Organik dan Pupuk Hayati. Balai Besar Litbang Sumberdaya Lahan Pertanian. Bogor. p 231-244.

Suriadikarta, D. A. dan R.D.M. Simanungkalit, 2006. Pendahuluan. Dalam Simanungkalit, R.D.M., D.A. Suriadikata, R. Saraswati, D. Setyorini, dan W. Hartatik. Pupuk Organik dan Pupuk Hayati. Balai Besar Litbang Sumberdaya Lahan Pertanian. Bogor. p 1-10.

Suryati. 2021. Pemanfaatan limbah air cucian beras untuk menyuburkan tanaman hias Aglonema. DPPP Kabupaten Bangka Selatan. https://dppp.bangkaselatankab.go.id/

Syamsiah, M. 2019. respon pertumbuhan dan produksi tanaman cabai merah (capsicum annum 1.) terhadap pemberian PGPR (plant growth promoting rhizobakteri) dari akar bambu dan urine kelinci. Agroscience (Agsci), 4(2): 109-114.

Tonfack, L.B., A. Bernadac, E. Youmbi, V.P. Mbouapouognigni, M. Ngueguim, and A. Akoa. 2009. Impact of organic and inorganic fertilizers on tomato vigor, yield and fruit composition under tropical andosol soil conditions. Fruits, 64(3): 167-177.

USDA-NRCS. 2019. Soil health. USDA-NRCS. https://www.nrcs.usda.gov/wps/portal/nrc s/main/soils/health. Diakses 3 Maret 2021.

Wahyudi, A. A., M. Maimunah, dan E. Pane. 2019. Respon pertumbuhan dan produksi kacang tanah (Arachis hypogaea L.) terhadap pemberian pupuk kandang kambing dan pupuk organik cair bonggol pisang. Jurnal Ilmiah Pertanian, 1(1): 18.

Walunguru, L. 2012. Kualitas pupuk organik cair dari urine sapi pada beberapa waktu simpan. Partner, 19(1): 26-32. 